\title{
Nitric oxide donors increase PVR/CD155 DNAM-1 ligand expression in multiple myeloma cells: role of DNA damage response activation
}

Cinzia Fionda ${ }^{1}$, Maria Pia Abruzzese ${ }^{1}$, Alessandra Zingoni ${ }^{1}$, Alessandra Soriani ${ }^{1}$, Biancamaria Ricci ${ }^{1}$, Rosa Molfetta ${ }^{1}$, Rossella Paolini ${ }^{1}$, Angela Santoni ${ }^{1,2^{*}}$ and Marco Cippitelli ${ }^{1 *}$

\begin{abstract}
Background: DNAX accessory molecule-1 (DNAM-1) is an activating receptor constitutively expressed by macrophages/ dendritic cells and by T lymphocytes and Natural Killer (NK) cells, having an important role in anticancer responses; in this regard, combination therapies able to enhance the expression of DNAM-1 ligands on tumor cells are of therapeutic interest. In this study, we investigated the effect of different nitric oxide (NO) donors on the expression of the DNAM-1 ligand Poliovirus Receptor/CD155 (PVR/CD155) in multiple myeloma (MM) cells.

Methods: Six MM cell lines, SKO-007(J3), U266, OPM-2, RPMI-8226, ARK and LP1 were used to investigate the activity of different nitric oxide donors [DETA-NO and the NO-releasing prodrugs NCX4040 (NO-aspirin) and JS-K] on the expression of PVR/CD155, using Flow Cytometry and Real-Time PCR. Western-blot and specific inhibitors were employed to investigate the role of soluble guanylyl cyclase/cGMP and activation of the DNA damage response (DDR).

Results: Our results indicate that increased levels of nitric oxide can upregulate PVR/CD155 cell surface and mRNA expression in MM cells; in addition, exposure to nitric oxide donors renders myeloma cells more efficient to activate NK cell degranulation and enhances their ability to trigger NK cell-mediated cytotoxicity. We found that activation of the soluble guanylyl cyclase and increased cGMP concentrations by nitric oxide is not involved in the up-regulation of ligand expression. On the contrary, treatment of MM cells with nitric oxide donors correlated with the activation of a DNA damage response pathway and inhibition of the ATM /ATR/Chk1/2 kinase activities by specific inhibitors significantly abrogates up-regulation.
\end{abstract}

Conclusions: The present study provides evidence that regulation of the PVR/CD155 DNAM-1 ligand expression by nitric oxide may represent an additional immune-mediated mechanism and supports the anti-myeloma activity of nitric oxide donors.

Keywords: Multiple myeloma, Nitric oxide, DNAM-1, Natural killer, DNA damage response, Chemoimmunotherapy

\section{Background}

Multiple myeloma (MM) is a deadly hematologic cancer characterized by latent accumulation of clonal secretory plasma cells in the bone marrow. Despite advances in therapeutic strategies, MM remains an incurable disease with a median survival around $4-5$ years in adults [1]. However, in the past decade, the use of autologous hematopoietic stem cell transplantation (HSCT) and the

\footnotetext{
* Correspondence: angela.santoni@uniroma1.it; marco.cippitelli@uniroma1.it 'Department of Molecular Medicine, Istituto Pasteur-Fondazione Cenci Bolognetti, Sapienza University of Rome, Viale Regina Elena 291, 00161 Rome, Italy
} ${ }_{2}^{2}$ Istituto Mediterraneo di Neuroscienze Neuromed, Pozzilli, IS, Italy introduction of new drugs, such as bortezomib and IMiDs, have improved survival [2-5].

Increasing evidence in myeloma patients has shown that Natural Killer (NK) cells can elicit potent allogeneic and autologous responses to myeloma cells, strongly supporting their anti-tumor potential in response to immunomodulatory drugs or following allogeneic stem cell transplantation [6-8]. In this regard, several studies have shown that triggering of different activating receptors, such as DNAX accessory molecule-1 (DNAM-1), NK group 2D (NKG2D) and Natural Cytotoxicity Receptors (NCRs), is involved in the recognition and killing of MM 
cells by NK cells [9-11]; moreover, MM cells can express the DNAM1-ligands (DNAM1Ls) PVR/CD155 and Nectin-2 (Nec-2) [12] and the NKG2D-ligands (NKG2DLs) MICA/B and ULBPs on the cell surface $[9,12,13]$.

Nitric oxide (NO) is a reactive radical, highly diffusible pleiotropic regulator of many different biological pathways, including vasodilatation, neurotransmission and macrophage-mediated responses to infections. It is generated from molecular oxygen and the amino acid $\mathrm{L}$-arginine through the action of the nitric oxide synthase (NOS) enzymes; three isoforms of NOS have been identified, a neuronal form (nNOS/NOS1) and endothelial form (eNOS/NOS3) which are both constitutively expressed enzymes producing physiological levels of NO, and an inducible form (iNOS/NOS2) which produces high levels of NO in a sustained manner [14-16]. In the last years, the relationship between $\mathrm{NO}$ and the pathology of malignant disorders has been the subject of numerous studies; although the three NOS isoforms are known to be present in most tumors and generally expressed at higher levels compared to their normal tissue counterparts, their functional role still remains incompletely elucidated $[17,18]$. In this regard, a concentration-dependent dual nature of $\mathrm{NO}$ has been revealed, where low concentrations of NO can promote invasion and metastases in different tumor models or, on the contrary, high NO levels (e.g. immune cell-generated $\mathrm{NO}$ ) and the different reactive nitrogen species (RNS) produced can inhibit tumor growth and metastases (reviewed in $[17,19,20]$ ). Thus, NO may play different roles in regulating cancer microenvironment and progression, which can be cell-type and context specific.

These observations suggest that tumor immune rejection through NO-dependent mechanism(s) can represent an interesting promise for future tailored immunotherapeutic anticancer strategies.

Our laboratory has recently shown that suboptimal doses of different drugs, such as genotoxic chemotherapeutics, inhibitors of the HSP-90 protein or of the GSK3 kinase, can increase the expression of several NK activating ligands on MM cells, via induction of specific regulatory transcriptional pathways [12,21,22]; the up-regulation of these ligands on MM cells is associated with their ability to trigger increased NK cell degranulation. At this regard, expression of DNAM-1 ligands and in particular PVR/CD155 can be regulated by activation of a DNA damage response (DDR) pathway induced by anticancer drugs (e.g. doxorubicin or melphalan) or, in a different context, by monocyte-derived reactive oxygen species (ROS) in Ag-induced T cell proliferation [23].

Here, we analyzed the possibility that treatment of MM cells with different NO-donors could regulate the expression of the NK cell activating ligand PVR/CD155 and, in turn, modify NK cell recognition and cytotoxicity against these cancer cells.

Our results indicate that increased levels of $\mathrm{NO}$ can enhance surface expression of PVR/CD155 on MM cell lines, rendering these cells more susceptible to NK cell mediated killing via DNAM-1 recognition. We found that activation a DDR by NO is critical for these mechanisms since pharmacological inhibition of ATM/ATR or Chk1/2 kinases as well as knockdown of E2F1, a transcription factor activated in response to DNA damage, significantly reduced NO-induced upregulation of PVR/ CD155.

Overall, our data demonstrate that $\mathrm{NO}$ can regulate DNAM-1 ligand expression on MM cells, suggesting novel roles of NO in immune response(s) to multiple myeloma.

\section{Methods}

\section{Cell lines}

The human MM cell lines SKO-007(J3), U266, OPM-2, ARK, RPMI-8226 and LP1 were kindly provided by Prof. P. Trivedi (Sapienza University of Rome, Italy). SKO-007 (J3) cells transduced with a lentiviral vector expressing shRNAs targeting E2F1 have been already described [24]. The erythroleukemia cell line K562 and MM cell lines were maintained at $37^{\circ} \mathrm{C}$ and $5 \% \mathrm{CO} 2$ in RPMI 1640 (Life Technologies, Gaithersburg, MD) supplemented with $10 \%$ FCS, $2 \mathrm{mM}$ glutamine and 100 units $/ \mathrm{ml}$ penicillin-streptomycin (complete medium). All cell lines were mycoplasma-free (EZ-PCR Mycoplasma Test Kit, Biological Industries).

\section{Reagents and antibodies}

The nitric oxide donors DETA-NO [2,2'-(hydroxynitrosohydrazono) bis-ethanimine], NCX4040 (NO-aspirin), JS-K [O2-(2,4-Dinitrophenyl) 1-[(4-ethoxycarbonyl)piperazin1-yl]diazen-1-ium-1,2-diolate], caffeine, LY294002 and the inhibitor of nitric oxide-sensitive guanylyl cyclase ODQ (1H-[1,2,4] Oxadiazolo[4,3-a]quinoxalin-1-one) and Bafilomycin A1, were purchased from Sigma-Aldrich (St. Louis, MO). The Chk1/2 pharmacologic inhibitors SB218078 and UCN-01 were purchased from Calbiochem, EMD Chemicals (Darmstadt, Germany). C12FDG was from Invitrogen (Frederick, MD). The nitric oxide donor DETA-NO (2 moles of NO• per mole of compound and a half-life of $20 \mathrm{~h}$ at $37^{\circ} \mathrm{C}$ ), is ideal for the treatment of cells over long periods of time (e.g. 24-48 h). JS-K (an anticancer agent belonging to the diazeniumdiolate family of compounds), is designed to release nitric oxide (NO) in a sustained and controlled manner within a cell, when metabolized by glutathione $S$-transferases (GSTs).

The following monoclonal antibodies (mAbs) were used for immunostaining or as blocking Abs: anti-PVR/CD155 (SKII.4) kindly provided by Prof. M. Colonna (Washington 
University, St Louis, MO), anti-CD56 (C218) mAb was provided by Dr. A. Moretta (University of Genoa, Genoa, Italy), anti-DNAM-1 (DX11) from Serotec (Oxford, UK), anti-Nec-2 (R2.525) from BD Biosciences (San Jose, CA), anti-TIGIT (MBSA43) from eBioscience Inc. (San Diego, CA). APC Goat anti-mouse IgG (Poly4053), anti-CD3/APC (HIT3a), anti-CD56/PE (HCD56), mouse IgG1/FITC, /PE or /APC isotype control (MOPC-21) were purchased from BioLegend (San Diego, CA). Anti-CD107a/FITC (H4A3) was purchased from BD Biosciences (San Jose, CA).

\section{Immunofluorescence and flow cytometry}

MM cell lines were cultured in 6-well tissue culture plates for $48 \mathrm{~h}$ at a concentration of $2 \times 10^{5}$ cells $/ \mathrm{ml}$ in the presence of different concentrations of drugs. The expression of PVR/CD155 on MM cells was analyzed by immunofluorescence staining using an anti-PVR/CD155 unconjugated $\mathrm{mAb}$, followed by secondary GAM-APC. In all experiments, cells were stained with Propidium Iodide (PI) $(1 \mu \mathrm{g} / \mathrm{ml})$ in order to assess cell viability (always higher than $90 \%$ in the different treatments). Nonspecific fluorescence was assessed by using an isotype-matched irrelevant $\mathrm{mAb}$ ( $R \& D$ System) followed by the same secondary antibody. Fluorescence was analyzed using a FACSCalibur flow cytometer (BD Bioscience, San Jose, CA) and FlowJo Flow Cytometric Data Analysis Software (Tree Star, Inc. Ashland, OR).

Intracellular $\mathrm{NO} \cdot$ levels were measured by flow cytometry in cells loaded with the NO-sensitive dye DAF2-DA [4,5-Diaminofluorescein-diacetate (Molecular Probes, Invitrogen, San Diego, CA)]. Cells were gated by forward/side scatter and fluorescence was recorded on the FL-1 channel according to the manufacturer's protocol.

\section{Degranulation assay}

NK cell-mediated cytotoxicity was evaluated using the lysosomal marker CD107a as previously described [21]. As source of effector cells, we used primary NK cells obtained from PBMCs isolated from healthy donors by Lymphoprep (Nycomed, Oslo, Norway) gradient centrifugation and then co-cultured for 10 days with irradiated (30 Gy) Epstein-Barr virus (EBV)-transformed B-cell line RPMI 8866, without the addition of recombinant IL-2, at $37^{\circ} \mathrm{C}$ in a humidified $5 \% \mathrm{CO} 2$ atmosphere as previously described [25]. Informed consent in accordance with the Declaration of Helsinki was obtained from all donors, and approval was obtained from the Ethics Committee of the Sapienza University of Rome, Italy. On day 10 , the cell population was routinely more than $90 \% \mathrm{CD}^{2} 6^{+} \mathrm{CD}_{16}{ }^{+} \mathrm{CD}^{-}$, as assessed by immunofluorescence and flow cytometry analysis. Drug-treated MM cells were washed twice in complete medium and then incubated with NK cells at the effector:target (E:T) ratio of 2.5:1, in a U-bottom 96-well tissue culture plate in complete medium at $37^{\circ} \mathrm{C}$ and $5 \% \mathrm{CO} 2$ for $2 \mathrm{~h}$. Thereafter, cells were washed with PBS and incubated with anti-CD107a/FITC (or cIgG/FITC) for $45 \mathrm{~min}$ at $4^{\circ} \mathrm{C}$. Cells were then stained with anti-CD3/APC, anti-CD56/ $\mathrm{PE}$ to gate the $\mathrm{CD}^{-} \mathrm{CD}^{-} 6^{+} \mathrm{NK}$ cell population. In some experiments, cells were pre-treated for $20 \mathrm{~min}$ at room temperature with anti-DNAM-1 or anti-TIGIT blocking $\mathrm{mAb}$. Fluorescence was analyzed using a FACSCalibur flow cytometer (BD Bioscience, San Jose, CA) and FlowJo Flow Cytometric Data Analysis Software (Tree Star, Inc. Ashland, OR).

\section{Cytotoxicity assay}

A standard 4-hour chromium-release assay was used as previously described [26]. SKO-007(J3) cells stimulated as indicated above, were used as target cells and were labeled $\left(100-200 \mu \mathrm{Ci}{ }^{51} \mathrm{Cr} / 10^{6}\right.$ cells; Amersham BioSciences, Piscataway, NJ) for 90 minutes at $37^{\circ} \mathrm{C}$, washed, and $5 \times 10^{3}$ cells/well were plated. As source of effector cells, we used primary NK cells as described above. The percentage of specific lysis was calculated by counting an aliquot of supernatant and using the formula: $100 \times[$ (sample release - spontaneous release)/total release - spontaneous release)]. All determinations were made in triplicate, and E:T ratios ranged from 10:1 to 1:1, as indicated.

\section{Cell cycle analysis}

SKO-007(J3) cell cycle distribution was analyzed by PI staining after $48 \mathrm{~h}$ drug treatment. Cells were washed in PBS with $0.1 \%$ sodium azide and fixed for $2 \mathrm{~h}$ at $4^{\circ} \mathrm{C}$ in cold $70 \%$ ethanol. Thereafter, cells were incubated for $30 \mathrm{~min}$ at room temperature with $50 \mu \mathrm{g} / \mathrm{mL}$ of PI in PBS containing $100 \mu \mathrm{g} / \mathrm{mL}$ of RNAse and immediately analyzed using a FACSCalibur flow cytometer. Flow cytometric analysis was performed using FlowJo software.

\section{Analysis of senescent cells}

Senescence Associated $\beta$-galactosidase assay was performed using the fluorogenic substrate C12FDG to measure $\beta$-galactosidase activity by flow cytometry. Cells were incubated $1 \mathrm{~h}$ with $100 \mathrm{nM}$ bafilomycin A1 to induce lysosomal alkalinization, followed by $1 \mathrm{~h}$ incubation with C12FDG $(33 \mu \mathrm{M})$ and the C12-fluorescein signal of senescent cells was measured on the FL-1 detector using a FACSCalibur flow cytometer. Flow cytometric analysis was performed using FlowJo software.

\section{RNA isolation, RT-PCR and real-time PCR}

Total RNA was extracted using TRIZOL ${ }^{\mathrm{ma}}$ (Life Technologies Inc., Grand Island, NY), according to manufacturer's instructions. The concentration and quality of the extracted total RNA was determined by measuring light absorbance at $260 \mathrm{~nm}\left(\mathrm{~A}_{260}\right)$ and the ratio of $\mathrm{A}_{260} / \mathrm{A}_{280}$. Reverse transcription was carried out in a $25 \mu$ l reaction volume 
with $2 \mu \mathrm{g}$ of total RNA according to the manufacturer's protocol for M-MLV reverse transcriptase (Promega, Madison, WI). Real-Time PCR was performed using the ABI Prism 7900 Sequence Detection system (Applied Biosystems, Foster City, CA). cDNAs were amplified in triplicate with primers for CD155/PVR (Hs00197846_m1) conjugated with fluorochrome FAM, and $\beta$-actin (4326315E) conjugated with fluorochrome VIC (Applied Biosystems). The level of ligand expression was measured using Ct (threshold cycle). The Ct was obtained by subtracting the $\mathrm{Ct}$ value of the gene of interest (PVR/CD155) from the housekeeping gene ( $\beta$-actin) $\mathrm{Ct}$ value. In the present study we used $\mathrm{Ct}$ of the untreated sample as the calibrator. The fold change was calculated according to the formula $2^{-\Delta \Delta \mathrm{Ct}}$, where $\Delta \Delta \mathrm{Ct}$ was the difference between $\mathrm{Ct}$ of the sample and the $\mathrm{Ct}$ of the calibrator (according to the formula, the value of the calibrator in each run is 1 . The analysis was performed using the SDS version 2.2 software (Applied Biosystems, Foster City, CA).

\section{Western-blot analysis}

For Western-Blot analysis, SKO-007(J3) cells were pelleted, washed once with cold phosphate-buffered saline, resuspended in lysis buffer [1\% Nonidet P-40 (v/v), 10\% glycerol, 0.1\% SDS, 0.5\% Sodium Deoxycholate, $1 \mathrm{mM}$ phenyl-methyl-sulfonyl fluoride (PMSF), $10 \mathrm{mM} \mathrm{NaF}$, $1 \mathrm{mM} \mathrm{Na} \mathrm{VO}_{4}$, COMPLETE protease1 inhibitor mixture (Roche, Indianapolis, IN) in PBS] and subsequently incubated $30 \mathrm{~min}$ on ice. The lysate was centrifuged at $14000 \mathrm{~g}$ for $15 \mathrm{~min}$ at $4^{\circ} \mathrm{C}$ and the supernatant was collected as whole cell extract. Protein concentration was determined by the BCA method (Pierce, Rockford, IL). Thirty to $50 \mu \mathrm{g}$ of cell extract were run on $10 \%$ denaturing SDS-polyacrylamide gels. Proteins were then electroblotted onto nitrocellulose membranes (Schleicher \& Schuell, Keene, NJ) and blocked in 3\% milk in TBST buffer. Immunoreactive bands were visualized on the nitrocellulose membranes, using horseradish-peroxidase-coupled goat anti-rabbit or goat anti-mouse immunoglobulins and the ECL detection system (GE Healthcare Amersham), following the manufacturer's instructions. Antibodies against phospho-Chk1 (Ser317), phospho-Chk2 (Thr68), total Chk1 and total Chk2 were purchased from Cell Signaling (Danvers, MA). Antibody against phospho-H2A.X was purchased from Millipore (Billerica, MA). Densitometric analysis was performed using Quantity One software (Bio-Rad, Hercules, CA).

\section{Results}

Nitric oxide upregulates expression of DNAM-1 ligand PVR/CD155 on human multiple myeloma cells

In order to characterize novel agents and molecular pathways able to regulate the expression of NK cell activating ligands in MM cells, we investigated the activity of nitric oxide donors [DETA-NO and the NO-releasing pro-drugs NCX4040 (NO-aspirin) and JS-K] on the expression of the CD155/PVR, an activating DNAM-1 ligand regulated by DDR and reactive radicals in different models [23,24]. We initially performed a flow cytometric analysis on SKO-007(J3) MM cells after 48 h-treatment with DETA$\mathrm{NO}$, a donor able to release 2 moles of $\mathrm{NO} \cdot$ per mole of compound and a half-life of $20 \mathrm{~h}$ at $37^{\circ} \mathrm{C}$, ideal for the treatment of cells over long periods of time (e.g. 24-48 h). As shown in Figure 1A and B treatment of SKO-007(J3) cells upregulated basal surface expression of PVR/CD155 ligand; the concentration of DETA-NO used in these experiments $(200 \mu \mathrm{M})$ has been chosen on the basis of dose-response assays using minimal doses of the donor [not affecting cell viability as assessed by PI staining (data not shown)], able to increase intracellular levels of $\mathrm{NO} \cdot$ and to induce optimal PVR/CD155 expression (Additional file $1 \mathrm{~A}$ and $\mathrm{D}$ ). At this regard, $200 \mu \mathrm{M}$ is within a concentration range of 0.1 to $1 \mathrm{mM}$ DETA-NO, already shown to be equivalent to about 200 to $400 \mathrm{nM} \mathrm{NO}$ concentrations over a 24/48-hour period and comparable with reported NO concentrations at different sites of active inflammation $[27,28]$.

Previous observations have shown that this cell line does not express detectable levels of the DNAM-1 ligand Nec-2/CD112, as well as the other cell lines used in this work (Additional file 2), and this ligand was not further analyzed in this study [21]. We next examined whether a possible mechanism underlying PVR/CD155 up-regulation on MM cells could be the consequence of an increased mRNA expression of this gene. Total RNA was isolated from SKO-007(J3) cells exposed to DETA-NO for $24 \mathrm{~h}$ and analyzed by Real-Time qRT-PCR. As shown in Figure $1 \mathrm{C}$, we found a significant increase of PVR/ CD155 mRNA levels in treated cells. We also investigated the effect of DETA-NO on other MM cell lines (U266, OPM-2, ARK, RPMI-8226 and LP-1) and confirmed that PVR/CD155 was similarly upregulated in all cell lines tested (Figure 1D-H). The concentration of DETA-NO used for the different cell lines has been chosen on the basis of dose-response assays using minimal doses of the donor not affecting cell viability and able to induce optimal PVR/CD155 expression (data not shown).

These results indicate that NO released by DETA-NO can enhance cell surface expression and mRNA levels of the DNAM-1 ligand PVR/CD155 in human MM cells.

\section{Exposure to nitric oxide increases degranulation and NK cell-mediated killing of MM cells}

We tested whether treatment of myeloma cells with DETA-NO could lead to increased activation and NK cell-mediated killing. To this aim, we analyzed the degranulation activity of NK cells derived from healthy 

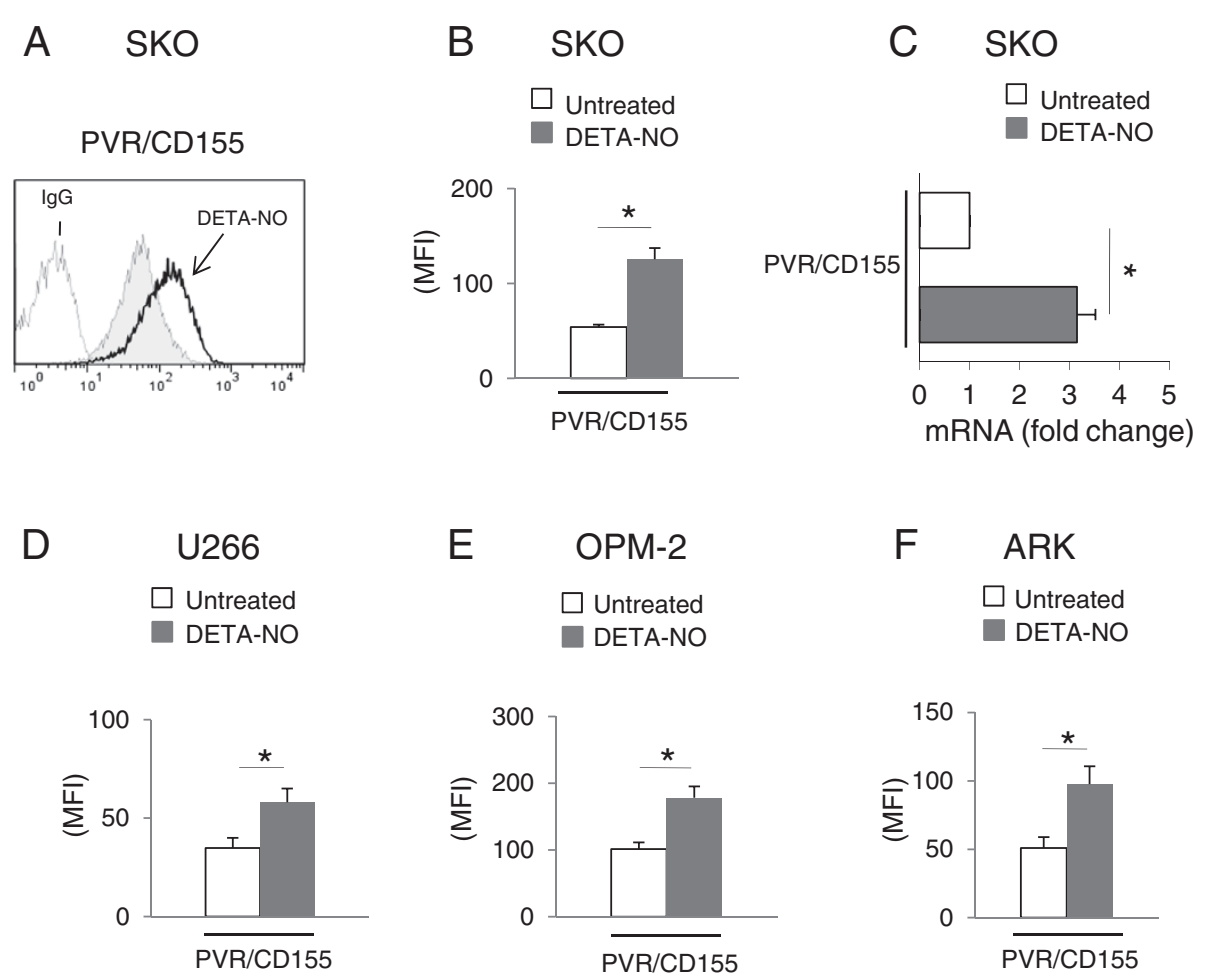

G

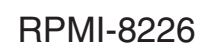

$\mathrm{H}$
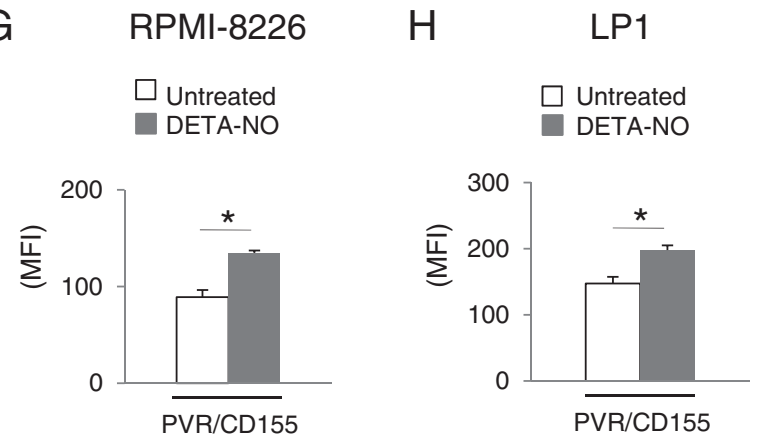

Figure 1 Regulation of PVR/CD155 expression on MM cell lines following treatment with NO donor DETA-NO. A) PVR/CD155 surface expression was analyzed by flow cytometry on SKO-007(J3) cells treated with DETA-NO (200 $\mu \mathrm{M})$ for $48 \mathrm{~h}$. Data are representative of one out of three independent experiments. The grey colored histogram represents basal expression, while thick black colored histogram represents the expression after treatment with DETA-NO. B) The MFI of PVR/CD155 surface expression was calculated based on at least four independent experiments and evaluated by paired Student $t$ test $\left.{ }^{*} P<0.05\right)$. Histograms represent the MFI with specific mAb subtracted from the MFI value of isotype control. These treatments did not affect the cell viability over the time and DETA-NO concentration [200 $\mu \mathrm{M}$ for SKO-007(J3)] chosen for these experiments (as assessed by PI staining, data not shown). C) Real Time PCR analysis of total mRNA obtained from SKO-007(J3) cells, untreated (-) or treated with $200 \mu \mathrm{M}$ DETA-NO for $24 \mathrm{~h}$ as described above. Data, expressed as fold change units, were normalized with $\beta$-actin and referred to the untreated cells considered as calibrator and represent the mean of 3 experiments $(* P<0.05)$. D-H) The MFI of PVR/CD155 surface expression was calculated for U266, OPM-2, ARK, RPMI-8226 and LP1 MM cells, based on at least three independent experiments and evaluated by paired Student $t$ test $\left({ }^{*} P<0.05\right)$. Histograms represent the MFI with specific mAb subtracted from the MFI value of isotype control. These treatments did not affect the cell viability over the time and DETA-NO concentration [200 $\mu \mathrm{M}$ for U266, $50 \mu \mathrm{M}$ for OPM-2, $200 \mu \mathrm{M}$ for ARK, $100 \mu \mathrm{M}$ for RPMI-8226 and $125 \mu \mathrm{M}$ for LP1] chosen for these experiments (as assessed by PI staining, data not shown).

donors against SKO-007(J3) cells, evaluating the expression of the CD107a (a surrogate marker for granule mobilization) by FACS analysis. As shown in Figure 2A and $\mathrm{B}$, basal expression of CD107a on NK cells contacting SKO-007(J3) was enhanced following treatment with
DETA-NO. This increased degranulation was partially dependent on DNAM-1 activation, because significantly reduced in the presence of a blocking anti-DNAM-1 $\mathrm{mAb}$. We also analyzed the possible role of the receptor TIGIT ( $\mathrm{T}$ cell Ig and ITIM domain), a coinhibitory 


\section{A}
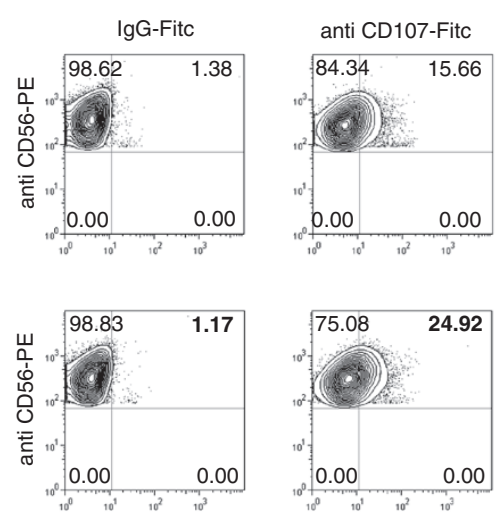

B
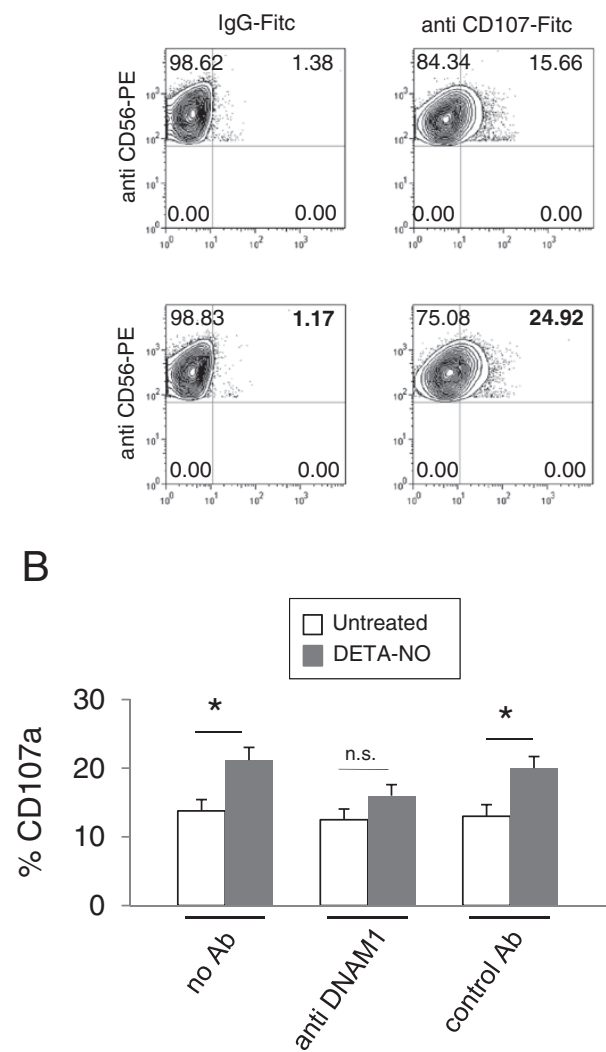
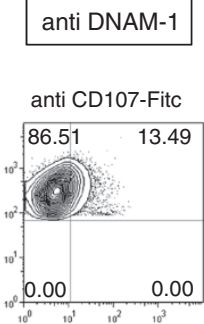

Untreated

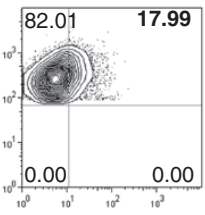

DETA-NO

\section{C}

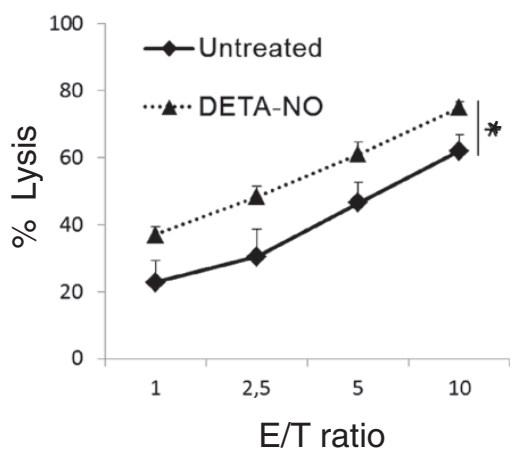

Figure 2 NO exposed SKO-007(J3) cells enhances NK cell-mediated cytotoxicity. A) NK cells prepared from PBMCs of healthy donors, were incubated with SKO-007(J3) cells, untreated or treated with DETA-NO for $48 \mathrm{~h}$, and used as target cells in a degranulation assay. The assay was performed at the effector:target (E:T) ratio of 2.5:1. After 2 hours at $37^{\circ} \mathrm{C}$, cells were stained with anti-CD56, anti-CD3 and anti-CD107a mAbs. Cell surface expression of CD107a was analyzed on $\mathrm{CD}_{5} 6^{+} \mathrm{CD}^{-}$cells. In order to evaluate the role of DNAM-1, the assay was performed in parallel treating NK cells with blocking anti-DNAM-1 antibody. Results are representative of one out of three independent experiments. B) The MFI of CD107 were calculated based on at least three independent experiments and evaluated by paired Student $t$ test $\left({ }^{*} P<0.05\right)$. Histograms represent the MFI with specific mAb subtracted from the MFI value of isotype control. C) NK cells isolated from PBMCs of healthy donors were incubated with SKO-007(J3) cells, untreated or treated with DETA-NO for $48 \mathrm{~h}$ as described above, and used as target cells in a standard 4-hour chromium-release assay. The percentage of specific lysis was calculated by counting an aliquot of supernatant and using the formula: $100 \times$ [(sample release spontaneous release)/total release - spontaneous release)]. All determinations were made in triplicate and E:T ratios ranged from 10:1 to 1:1, as indicated. Data represent the mean $\left(n=3\right.$ experiments, $\left.{ }^{*} P<0.05\right)$.

receptor that also binds to PVR/CD155 and Nec-2 ligands, expressed in NK cells as well as in different $\mathrm{T}$ cell subsets [29,30]; as shown in Additional file 3, the presence of a blocking anti-TIGIT mAb did not significantly modify basal or the increased degranulation induced by DETA-NO, suggesting that triggering of this receptor is not able to modulate the activity of NK cells, at least in this experimental setting. As a control for a possible direct effect of NO on NK cell functions, we also analyzed the degranulation activity of NK cells contacting SKO007(J3) cells in the presence of DETA-NO; as shown in Additional file 4, degranulation activity was not significantly affected by the presence of the donor.

Finally, we analyzed the effect of DETA-NO on NK cell cytolytic function; as shown in Figure $2 \mathrm{C}$, standard cytotoxicity assays using ${ }^{51} \mathrm{Cr}$-labeled SKO-007(J3) target cells were performed, and treatment with DETA-NO significantly increased specific killing when compared to the cytotoxicity of untreated cells.

Our results, therefore, indicate that increased expression of PVR/CD155 in SKO-007(J3) cells treated with DETA-NO enhances NK cell degranulation and killing by promoting DNAM-1 recognition.

\section{Molecular mechanisms involved in PVR/CD155 up-regulation by NO}

One of the most studied mechanisms involved in physiological pathways regulated by $\mathrm{NO}$ is the activation of the heme iron in the soluble guanylate cyclase (sGC), able to stimulate cGMP production and activation of downstream 
signalling [31,32]. To determine whether this molecular pathway might be involved in PVR/CD155 up-regulation in MM cells, SKO-007(J3) cells were treated with DETA$\mathrm{NO}$ in the presence or absence of ODQ, a widely used specific inhibitor of soluble guanylate cyclase used to differentiate cGMP-mediated effects of NO from cGMPindependent effects $[33,34]$. However, as shown in Figure 3A, up-regulation of PVR/CD155 was not affected by ODQ, suggesting that cGMP-mediated signalling was not involved.

Nitric oxide can also interact directly with biological target molecules, nonetheless, when generated in high amounts such as during inflammation, it can exert indirect effects, reacting with superoxide anion to produce different reactive nitrogen species (RNS) [e.g. peroxynitrite (a strong oxidant)] with significant pathophysiological/inflammatory actions (reviewed in [35,36]). In this regard, the different actions of $\mathrm{NO}$ in tumor biology may be in part explained by the complex dose-dependent interactions of NO and the related RNS with DNA, producing both single and double-strand breaks and genotoxic stress
$[20,37]$. As our laboratory has recently shown that genotoxic drugs (e.g. melphalan or doxorubicin) can trigger the expression of NK activating ligands on MM cells in an ATM/ATR/Chk1/2-dependent and p53-independent manner [12,24], we investigated the possibility that a similar mechanism might be involved in the presence of NO donors. We analyzed the activation of ATM/ATRdependent down-stream signalling components, such as H2A.X and Chk1/2 kinases, already described to phosphorylate and activate effector proteins that inhibit cell cycle progression and to activate DNA repair [38,39]; as shown in Figure 3B and C, DETA-NO was able to induce H2A.X phosphorylation on residue Ser139 (pH2A.X) and Chk1 and Chk2 phosphorylation on Ser317 and Thr68, respectively. In this regard, as shown in Figure $4 \mathrm{~A}$ and $\mathrm{B}$ (and Additional file 5A,B), up-regulation of PVR/CD155 expression was significantly inhibited by caffeine or by LY294002 in SKO-007(J3) cells, two widely used inhibitors capable of blocking both ATM and ATR catalytic activity [40], and by SB218078 or UCN-01, inhibitors of Chk1/2 kinases (Figure 4C,D and Additional file 5C,D).
A

PVR/CD155

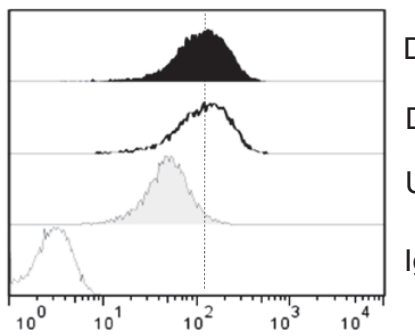

B

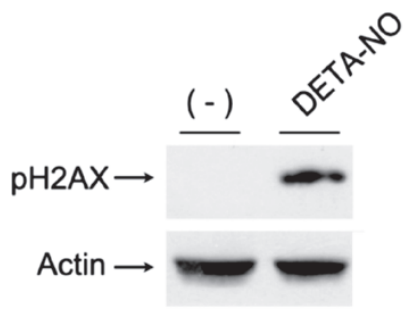

DETA-NO + ODQ

DETA-NO

Unstim.

$\lg G$

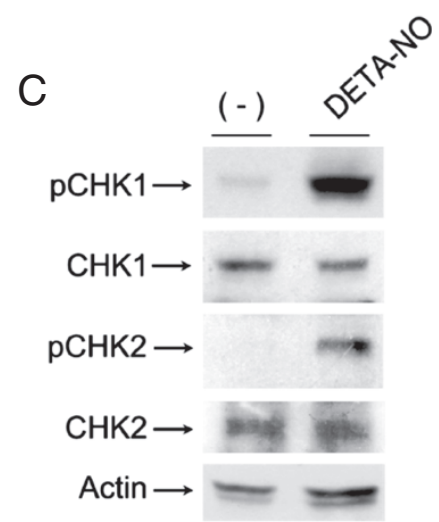

Figure 3 NO enhances PVR/CD155 expression: molecular mechanisms. A) PVR/CD155 surface expression was analyzed by flow cytometry on SKO-007(J3) cells treated with DETA-NO $(200 \mu \mathrm{M})$ in the presence or absence of the guanylate cyclase inhibitor ODQ $(50 \mu \mathrm{M})$ for $48 \mathrm{~h}$. Data are representative of one out of three independent experiments. B) Western Blot analysis of total cellular proteins from SKO-007(J3) cells treated with DETA-NO for $18 \mathrm{~h}$. The arrow indicates the expression of the pH2A.X and $\beta$-actin, used as loading control. The proteins transferred to nitrocellulose membranes were stained with Ponceau to verify that similar amounts of protein had been loaded in each lane. Data shown are representative of 1 out of 2 independent experiments. C) Western Blot analysis of total cellular proteins from SKO-007(J3) cells treated with DETA-NO for 18 h. Lysates were probed with antibodies to different phosphorylation sites of Chk1 and Chk2, wt Chk1 and Chk2 or $\beta$-actin, used as loading control. The proteins transferred to nitrocellulose membranes were stained with Ponceau to verify that similar amounts of protein had been loaded in each lane. Data shown are representative of 1 out of 2 independent experiments. 
A

PVR/CD155

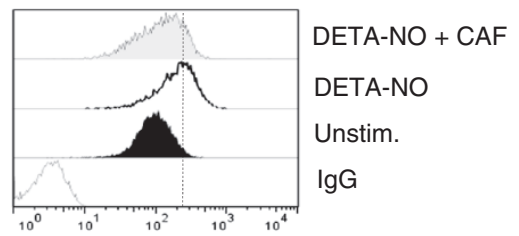

C

PVR/CD155

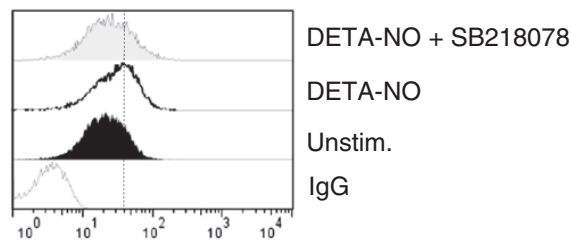

E

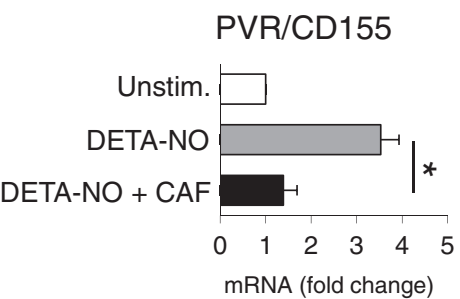

G

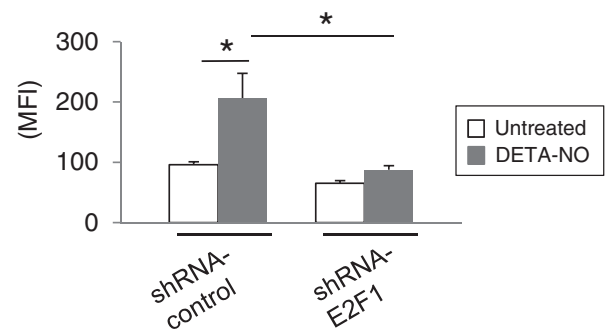

B PVR/CD155

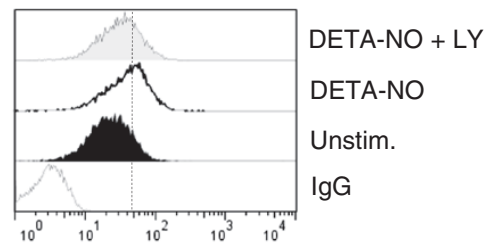

D PVR/CD155

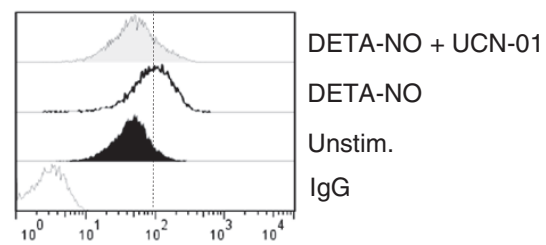

F
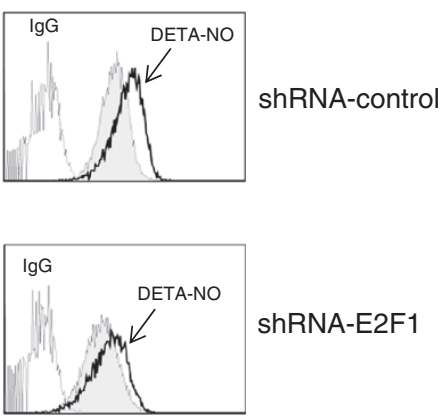

Figure 4 NO enhances PVR/CD155 expression: role of DDR. A,B) PVR/CD155 surface expression was analyzed by flow cytometry on SKO-007 (J3) cells treated with DETA-NO (200 $\mu \mathrm{M})$ in the presence or absence of caffeine (CAF $1 \mathrm{mM})$ or LY294002 (LY $20 \mu \mathrm{M})$ for $48 \mathrm{~h}$. Data are representative of one out of four independent experiments. C,D) PVR/CD155 surface expression was analyzed by flow cytometry on SKO-007(J3) cells treated with DETA-NO $(200 \mu \mathrm{M})$ in the presence or absence of the Chk1/2 inhibitors SB218078 and UCN-01 (0.5 $\mu \mathrm{M}$ and $50 \mathrm{nM}$ respectively) for $48 \mathrm{~h}$. Data are representative of one out of four independent experiments. In these experiments, the concentration used for the different inhibitors, did not significantly affect cell viability as assessed by PI staining (data not shown). E) Real Time PCR analysis of total mRNA obtained from SKO-007(J3) cells, treated for $24 \mathrm{~h}$ in the presence or absence of caffeine $(1 \mathrm{mM})$ as described above. Data, expressed as fold change units, were normalized with $\beta$-actin and referred to the untreated cells considered as calibrator and represent the mean of 3 experiments $\left({ }^{*} P<0.05\right)$. F) PVR/CD155 surface expression was analyzed by flow cytometry on SKO-007(J3) non-target shRNA (shRNA-control) or pLKO-sh-E2F1 cells, treated with DETA-NO as described above. Data are representative of one out of three independent experiments. G) The MFI of PVR/CD155 surface expression was calculated based on at least three independent experiments and evaluated by paired Student $t$ test $\left({ }^{*} P<0.05\right)$. Histograms represent the MFI with specific $\mathrm{mAb}$ subtracted from the MFI value of isotype control.

Accordingly, we also found a significant inhibition of PVR/CD155 mRNA levels in DETA-NO + caffeinetreated cells (Figure 4E) and, in addition, up-regulation of PVR/CD155 expression was significantly inhibited in SKO-007(J3) cells in which the expression of E2F1 was reduced by shRNA interference (already described in [24]), a transcription factor activated/stabilized by ATM/ATR and Chk2 [41-43] and recently shown to 
upregulate the expression of PVR/CD155 in MM cells exposed to genotoxic drugs [24]. These results indicate that NO-mediated activation of DDR is involved in the up-regulation of PVR/CD155 in MM cells.

\section{NO/DDR-induced up-regulation of PVR/CD155 is not related to a senescence-dependent mechanism}

We have previously demonstrated that genotoxic drugs (e.g. doxorubicin)-induced up-regulation of PVR/CD155 is associated with a senescence-dependent $\mathrm{G} 2 / \mathrm{M}$ cell cycle arrest in MM cells [12]. Here, we investigated the possible link between DDR, cell cycle, induction of senescence and the ability of $\mathrm{NO}$ to induce PVR/CD155 expression. As shown in Figure 5A, stimulation of SKO007(J3) cells with DETA-NO or with doxorubicin increased basal cell surface expression of PVR/CD155; however, only doxorubicin could activate a senescencedependent G2/M cell cycle arrest (Figure 5B and C) as indicated by the different levels of SA- $\beta$ Gal activity and G2/M quantification. These data suggest that different (DDR)-related pathways may be triggered by these drugs and that cellular senescence is not correlated or involved in NO-induced up-regulation of PVR/CD155 in MM cells.

\section{Anticancer nitric oxide-releasing prodrugs upregulates expression of PVR/CD155 on human multiple myeloma cells}

Rational design of pharmacological agents (including NO-donors) takes account of specific modifications of known molecules with the purpose of optimizing their properties mainly in terms of efficacy and safety. In this context, the use of compounds that generate NO spontaneously for the treatment of malignancies is precluded due to the potential general toxic effects of NO. Thus, we investigated also the activity of novel prototype anticancer
A
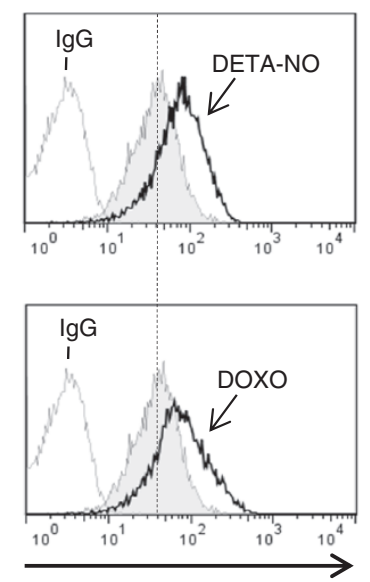

PVR/CD155
B
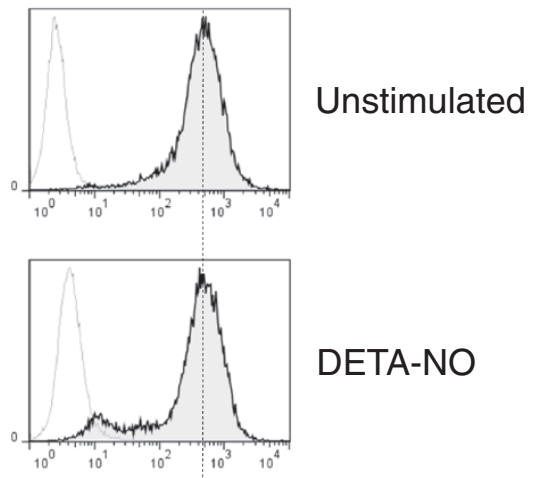

DETA-NO

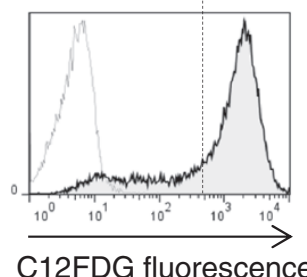

C

Unsimulated

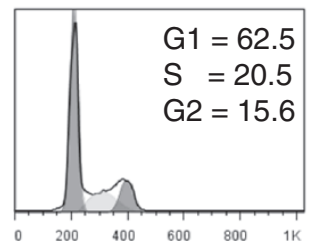

DETA-NO

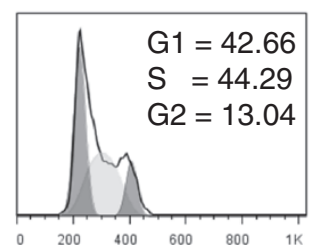

Doxorubicin

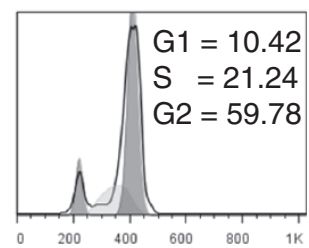

Figure 5 NO-induced up-regulation of PVR/CD155 is not related to a senescence-dependent mechanism. A) PVR/CD155 surface expression was analyzed by flow cytometry on SKO-007(J3) cells treated with DETA-NO (200 $\mu \mathrm{M})$ or with doxorubicin $(0.05 \mu \mathrm{M})$ for $48 \mathrm{~h}$. Data are representative of one out of three independent experiments. The grey colored histograms represent basal expression of the indicated ligand, while thick black colored histograms represent the expression after treatment with the indicated drug. B) SA- $\beta$ Gal activity of SKO-007(J3) cells treated with DETA-NO or with doxorubicin for $48 \mathrm{~h}$ as described above. Data are representative of one out of three independent experiments. The grey colored histograms represent the C12-fluorescein signal. C) SKO-007(J3) cells were treated for 48 hours with the indicated drug as described above. Cells were fixed and stained with PI to analyze cell distribution among the different cell-cycle phases. 
NO-releasing prodrugs on the expression of PVR/CD155. To this aim, we treated SKO-007(J3) cells with the NOreleasing aspirin derivative NCX4040 (a bio-activated nitric oxide-donating non-steroidal anti-inflammatory drug) [44] or with JS-K, an anti-cancer agent designed to release nitric oxide in a sustained manner within a cell when metabolized by glutathione $S$-transferases (GSTs), enzymes frequently overexpressed in different tumors, including MM $[45,46]$. The concentration of donors used in these experiments have been chosen on the basis of dose-response assays using minimal doses of the specific donor (not affecting cell viability as assessed by PI staining, data not shown), able to induce optimal PVR/CD155 expression (Additional file $1 \mathrm{~B}$ and $\mathrm{C}$ ).

As shown in Figure 6, treatment of SKO-007(J3) cells with NCX4040 or with JS-K at micromolar concentrations (known to generate significant levels of intracellular NO in different cell lines, including MM [44-46]), upregulated the basal cell surface expression of PVR/CD155, confirming the data obtained using DETA-NO and suggesting the use of novel NO-releasing prodrugs as an additional class of regulators of the expression of DNAM-1 ligand in cancer cells.

\section{Discussion and conclusion}

Anticancer immune responses may contribute to the control of tumors after conventional chemotherapy and different observations have indicated that chemotherapeutic agents (e.g. genotoxic drugs) or adjuvant radiotherapy can induce immune responses that result in immunogenic cancer cell death or immunostimulatory side effects [47-50]. In this regard, increasing experimental and clinical evidence highlight the importance of NK cells in immune responses toward MM and combination therapies able to enhance the activity of NK cells against MM are showing promise in treating this hematologic cancer. Recently, a novel connection between therapeutic immuno-modulation and chemotherapy has been the finding that anti-cancer drugs (e.g. genotoxic agents, inhibitors of histone deacetylases, of the proteasome or of the HSP-90 chaperone) can increase the expression of DNAM-1 and NKG2D activating ligands, thus enhancing
A

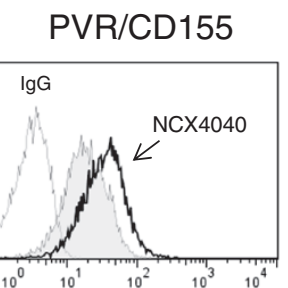

D

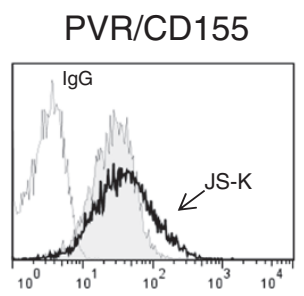

B

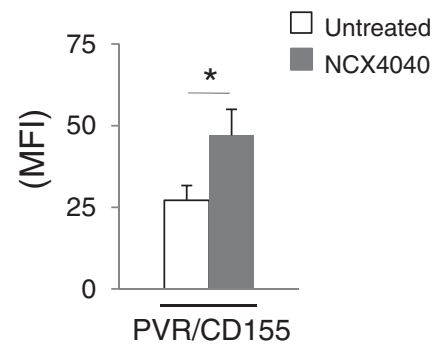

E

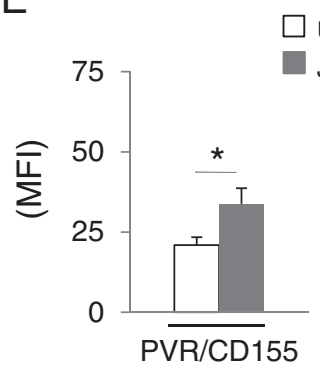

Untreated

JS-K
C<smiles>CC(=O)Oc1ccccc1C(=O)Oc1ccc(CON(C)C)cc1</smiles>

NCX4040

NitroAspirin

F<smiles>COC(=O)N1CCN(N[N+](=O)ON(C)C(=O)O[Na])CC1</smiles>

JS-K

Figure 6 Regulation of PVR/CD155 expression on MM cell lines following treatment with the NO-releasing prodrugs NitroAspirin and JS-K. A) PVR/CD155 surface expression was analyzed by flow cytometry on SKO-007(J3) cells treated with NCX4040 (10 $\mu$ M) for 48 h. Data are representative of one out of three independent experiments. The grey colored histogram represents basal expression of the indicated ligand, while thick black colored histogram represents the expression after treatment with NCX4040. B) The MFI of PVR/CD155 surface expression was calculated based on at least three independent experiments and evaluated by paired Student $t$ test $\left({ }^{*} P<0.05\right)$. Histograms represent the MFI with specific mAb subtracted from the MFI value of isotype control. C) Molecular structure of NCX4040. D) PVR/CD155 surface expression was analyzed by flow cytometry on SKO-007(J3) cells treated with JS-K (3 $\mu \mathrm{M})$ for $48 \mathrm{~h}$. Data are representative of one out of three independent experiments. The grey colored histogram represents basal expression of the indicated ligand, while thick black colored histogram represents the expression after treatment with JS-K. E) The MFI of PVR/CD155 surface expression was calculated based on at least three independent experiments and evaluated by paired Student $t$ test $\left({ }^{*} P<0.05\right)$. Histogram represents the MFI with specific mAb subtracted from the MFI value of isotype control. F) Molecular structure of JS-K. The concentration of the indicated donor used in these experiments, did not significantly affect cell viability as assessed by PI staining (data not shown). 
the response of receptor-expressing lymphocytes (NK cells, NKT cells and CTLs) against tumor cells, including MM [11,12,21,24,51-54].

Different and contradictory results have been reported about the role of nitric oxide in cancer progression, metastases and treatment of disease (reviewed in $[19,20]$ ). Initial findings suggested that immune cell-generated $\mathrm{NO}$ can be cytostatic or cytotoxic for a number of tumors; indeed, several reports have shown that macrophages can selectively destroy different tumor types (in vitro and in vivo) through the production of high levels of NO [55-58]. Moreover, NO can also enhance the cytotoxicity of NK cells and regulate survival of dendritic cells [59-61] and its release in models of lung and hepatic metastases microvasculature has been associated to a natural local defense mechanism inducing tumor cell killing $[62,63]$. On the other hand, other findings highlighted opposite actions mediated by NO, leading to increased tumor growth; in this context, low concentrations of NO have been shown to promote invasion and metastases (reviewed in $[17,20]$ ) and production of $\mathrm{NO}$ within specific tumor microenvironments has been described to enhance tumor progression, mainly by stimulating angiogenesis and/or to repress $\mathrm{T}$ cell responses by $\mathrm{CD} 11 \mathrm{~b}^{+} / \mathrm{Gr}-1^{+}$myeloid cells (reviewed in [17]).

The observations described in this work can provide additional information on the role of nitric oxide in cancer and in MM. In particular, we investigated the effect of nitric oxide on the expression of the DNAM-1 ligand PVR/CD155 in MM cells. We found that treatment of MM cell lines with nitric oxide donors (DETA-NO, NitroAspirin/NCX4040 or JS-K) can increase the expression of this ligand, rendering these cells more susceptible to NK cell-mediated killing (Figure 2). Moreover, we identified one of the possible mechanism(s) involved in this up-regulation, the activation of a DNA damage response, a molecular pathway already described to regulate the expression of NK cells activating ligands in several cellular models $[12,24,64]$. NO-generated nitrogen species [20,37] and the consequent production of single and/or double DNA strand breaks can activate DDR in MM cells (as shown in Figure 3B and C); in this regard, upregulation of PVR/CD155 by DETA-NO was significantly reduced by inhibitors of ATM/ATR catalytic activity (caffeine and LY294002) and by inhibitors of the Chk $1 / 2$ kinases (SB218078 and UCN-01) (Figure 4C-D). In addition, silencing of E2F1, a transcription factor activated/stabilized by ATM/ATR/Chk2 [41-43] and described to upregulate the expression of PVR/CD155 in MM cells exposed to genotoxic drugs [24], resulted in a marked reduction of PVR/ CD155 up-regulation (Figure 4E and F). These results indicate that NO-mediated activation of DDR is involved in the up-regulation of PVR/CD155 and that one of the mechanism(s) underlying this regulation implicates the activity of E2F1. Interestingly, and differently from our previous observation that up-regulation of PVR/CD155 is preferentially associated with a senescence-dependent G2/ $\mathrm{M}$ cell cycle arrest [12], NO failed to activate a senescence and G2/M cell cycle arrest in our experimental system, as indicated by the different levels of SA- $\beta$ Gal activity and G2/M phase between DETA-NO and doxorubicin-treated cells (used here as positive control) (Figure $5 \mathrm{~B}$ and $\mathrm{C}$ ). These data suggest that specific molecular pathways activated by RNSs and/or a different strength of DDR might be induced by these drugs and that cellular senescence is not correlated or involved in up-regulation of PVR/ CD155. Moreover, the three NO-donors used in this work differ in their capability to upregulate PVR/CD155 expression, at least in our experimental setting of donor concentration and duration of treatment (as shown in Figures 1 and 6); these differences might reflect the possibility that additional molecular action(s) besides $\mathrm{NO}$ release might contribute to donors biologic activities, in particular mediated by the aspirin-moiety (NCX4040) or by the JS-K's arylating ability on different nucleophilic biomolecules [65]. Further experiments will be needed to better characterize possible differences in activation of DDR by these drugs and the correlation with the expression of activating ligands.

Work by other groups has demonstrated a direct cytotoxic/anti-myeloma activity of $\mathrm{NO}$ as a consequence of induction of DDR, using the NO-releasing prodrug JS$\mathrm{K}$ [46], which can also affect the interaction of MM cells with bone marrow microenvironment, modulating tumor angiogenesis in vivo and in vitro [66]. Moreover, NO can function as a negative feedback signal to limit pathologic osteoclastogenesis via RANKL/iNOS/NO autoregulatory pathway [67]. In a different context, treatment with JS-K or the activation of macrophage-dependent NO expression after IL-2 + anti-CD40 immunotherapy has been shown to modulate metastatic progression in an orthotopic model of renal cell carcinoma [68]. Similarly, local production of significant amounts of $\mathrm{NO}$ by iNOS ${ }^{+}$has been also shown to deeply affect the activity of pro-tumoral microenvironments, as demonstrated using neoadjuvant local low-doses of gamma irradiation (LDI) in a model of pancreatic carcinogenesis [69]; in this model, LDI is able to redirect local (or pre-adoptive-transfer) macrophage differentiation from a cancer-promoting immunosuppressive state to an iNOS ${ }^{+}$phenotype, to normalize aberrant angiogenesis-driven vascular abnormalities and to enable infiltration of cytotoxic T cells. In this regard, local $\mathrm{MM}$-associated macrophages play a crucial role in the pathophysiology of MM and can promote plasma cell growth with aberrant vasculogenesis (reviewed in [70]); moreover, hypoxia-mediated impairment of NO signalling can also contribute to tumor escape from NK cell 
immunesurveillance by inducing shedding of the NKG2DL MICA, through a mechanism involving increased expression/activity of ADAM10 via HIF- $1 \alpha[71,72]$.

The possibility to regulate activating ligands such as PVR/CD155 in MM cells, able to enhance the activity of cytotoxic lymphocytes (e.g. NK cells) by pharmacological delivery of NO-releasing prodrugs (also in combined immunotherapy) or local production of NO by "therapyreprogrammed" or adoptively transferred $\mathrm{iNOS}^{+}$macrophages, might be considered as an additional strategy to hit the tumor and to modify local microenvironment allowing and/or enhancing immuno-therapeutic applications.

\section{Additional files}

\begin{abstract}
Additional file 1: A-C) Dose-response assays using minimal doses of the indicated donor (not affecting cell viability as assessed by PI staining, data not shown) able to induce optimal PVR/CD155 expression in SKO-007(J3) cells after $\mathbf{4 8} \mathrm{h}$ treatment. The optimal doses chosen (indicated in bold) were: DETA-NO $200 \mu \mathrm{M}$, NCX4040 10 $\mu \mathrm{M}$, JS-K $3 \mu \mathrm{M}$. D) Intracellular NO levels in SKO-007(J3) cells after $24 \mathrm{~h}$ treatment with DETA-NO $200 \mu \mathrm{M}$.
\end{abstract}

Additional file 2: Nec-2/CD112 surface expression was analyzed by flow cytometry on SKO-007(J3), U266, OPM-2, ARK, RPMI-8226 and LP1 MM cells. K562 cells were used here as positive control. The thin black colored histogram represents lgG-control while grey colored histogram represents the expression of $\mathrm{Nec}-2$.

Additional file 3: NK cells prepared from PBMCs of healthy donors were incubated with SKO-007(J3) cells, untreated or treated with DETA-NO for $\mathbf{4 8} \mathrm{h}$, and used as target cells in a degranulation assay. The assay was performed at the effector:target (E:T) ratio of 2.5:1. After 2 hours at $37^{\circ} \mathrm{C}$, cells were stained with anti-CD56, anti-CD3 and anti-CD107a mAbs. Cell surface expression of CD107a was analyzed on $\mathrm{CD}^{2} 6^{+} \mathrm{CD}^{-}$cells. In order to evaluate the role of TIGIT, the assay was performed in paralle treating NK cells with blocking anti-TIGIT antibody. Results are representative of one out of two independent experiments.

Additional file 4: NK cells prepared from PBMCs of healthy donors were incubated with SKO-007(J3) cells as described above, and used as target cells in a degranulation assay. The assay was performed at the effector:target (E:T) ratio of 2.5:1, in the presence or in the absence of DETA-NO $200 \mu \mathrm{M}$. After 2 hours at $37^{\circ} \mathrm{C}$, cells were stained with anti-CD56, anti-CD3 and anti-CD107a mAbs. Cell surface expression of CD107a was analyzed on $\mathrm{CD}_{56}{ }^{+} \mathrm{CD}_{3}^{-}$cells. Results are representative of one out of two independent experiments.

Additional file 5: A,B) PVR/CD155 surface expression was analyzed by flow cytometry on SKO-007(J3) cells treated with DETA-NO $(200 \mu \mathrm{M})$ in the presence or absence of caffeine (CAF $1 \mathrm{mM}$ ) or LY294002 (LY $20 \mu \mathrm{M})$ for $\mathbf{4 8} \mathrm{h}$. C,D) PVR/CD155 surface expression was analyzed by flow cytometry on SKO-007(J3) cells treated with DETA-NO (200 $\mu \mathrm{M})$ in the presence or absence of the Chk1/2 inhibitors SB218078 and UCN-01 (0.5 $\mathrm{MM}$ and $50 \mathrm{nM}$ respectively) for $48 \mathrm{~h}$. The MFI of PVD/CD 155 expression was calculated based on at least four independent experiments and evaluated by paired Student $t$ test $\left.{ }^{*} P<0.05\right)$. Histograms represent the MFI with specific mAb subtracted from the MFI value of isotype control.

\section{Abbreviations}

DDR: DNA Damage Response; DNAM-1: DNAX accessory molecule-1; GSTs: Glutathione S-transferases; MM: Multiple Myeloma; NCR: Natural Cytotoxicity Receptors; Nec-2: Nectin-2-CD112; NKG2D: NK group 2D; PVR: Poliovirus receptor-CD155; RNS: Reactive nitrogen species; ROS: Reactive oxygen species; TIGIT: T cell Ig and ITIM domain.

\section{Competing interests}

The authors declare that they have no competing interests.

\section{Authors' contributions}

CF designed research, performed experiments, and contributed to paper writing. MPA, AZ, ASo, BR, RM, RP, performed experiments. MC and ASa designed research, and contributed equally to paper writing and supervising the laboratory activities. All authors read and approved the final manuscript.

\section{Acknowledgments}

The authors thank Dina Milana, for expert technical assistance. This study was supported by grants from the Italian Association for Cancer Research (AIRC), 5×1000 AIRC, Ministero della Salute, Ateneo, MIUR (PRIN/2010NECHBX_004/Marco Cippitelli).

Received: 1 October 2014 Accepted: 14 January 2015

Published online: 22 January 2015

\section{References}

1. Kumar SK, Rajkumar SV, Dispenzieri A, Lacy MQ, Hayman SR, Buadi FK, et al. Improved survival in multiple myeloma and the impact of novel therapies. Blood. 2008:111:2516-20.

2. Kyle RA, Rajkumar SV. Multiple myeloma. Blood. 2008;111:2962-72.

3. Mahindra A, Laubach J, Raje N, Munshi N, Richardson PG, Anderson K. Latest advances and current challenges in the treatment of multiple myeloma. Nat Rev Clin Oncol. 2012;9:135-43.

4. Mohty B, El-Cheikh J, Yakoub-Agha I, Avet-Loiseau H, Moreau P, Mohty M. Treatment strategies in relapsed and refractory multiple myeloma: a focus on drug sequencing and 'retreatment' approaches in the era of novel agents. Leukemia. 2012;26:73-85.

5. Ludwig H, Durie BG, McCarthy P, Palumbo A, San MJ, Barlogie B, et al. IMWG consensus on maintenance therapy in multiple myeloma. Blood. 2012:119:3003-15.

6. Frohn C, Hoppner M, Schlenke P, Kirchner H, Koritke P, Luhm J. Anti-myeloma activity of natural killer lymphocytes. Br J Haematol. 2002;1 19:660-4.

7. Hayashi T, Hideshima T, Akiyama M, Podar K, Yasui H, Raje N, et al. Molecular mechanisms whereby immunomodulatory drugs activate natural killer cells: clinical application. Br J Haematol. 2005;128:192-203.

8. Koh CY, Raziuddin A, Welniak LA, Blazar BR, Bennett M, Murphy WJ. NK inhibitory-receptor blockade for purging of leukemia: effects on hematopoietic reconstitution. Biol Blood Marrow Transplant. 2002;8:17-25.

9. Carbone E, Neri P, Mesuraca M, Fulciniti MT, Otsuki T, Pende D, et al. HLA class I, NKG2D, and natural cytotoxicity receptors regulate multiple myeloma cell recognition by natural killer cells. Blood. 2005;105:251-8.

10. El Sherbiny YM, Meade JL, Holmes TD, McGonagle D, Mackie SL, Morgan AW, et al. The requirement for DNAM-1, NKG2D, and NKp46 in the natural killer cell-mediated killing of myeloma cells. Cancer Res. 2007:67:8444-9.

11. Jinushi M, Vanneman M, Munshi NC, Tai YT, Prabhala RH, Ritz J, et al. MHC class I chain-related protein A antibodies and shedding are associated with the progression of multiple myeloma. Proc Natl Acad Sci U S A. 2008:105:1285-90.

12. Soriani A, Zingoni A, Cerboni C, lannitto ML, Ricciardi MR, Di Gialleonardo V, et al. ATM-ATR-dependent up-regulation of DNAM-1 and NKG2D ligands on multiple myeloma cells by therapeutic agents results in enhanced NK-cell susceptibility and is associated with a senescent phenotype. Blood. 2009:113:3503-11.

13. Girlanda S, Fortis C, Belloni D, Ferrero E, Ticozzi P, Sciorati C, et al. MICA expressed by multiple myeloma and monoclonal gammopathy of undetermined significance plasma cells Costimulates pamidronate-activated gammadelta lymphocytes. Cancer Res. 2005;65:7502-8.

14. Bredt DS, Hwang PM, Glatt CE, Lowenstein C, Reed RR, Snyder SH. Cloned and expressed nitric oxide synthase structurally resembles cytochrome P-450 reductase. Nature. 1991;351:714-8.

15. Robinson $\sqcup$, Weremowicz S, Morton CC, Michel T. Isolation and chromosomal localization of the human endothelial nitric oxide synthase (NOS3) gene. Genomics. 1994;19:350-7.

16. Lowenstein CJ, Glatt CS, Bredt DS, Snyder SH. Cloned and expressed macrophage nitric oxide synthase contrasts with the brain enzyme. Proc Natl Acad Sci U S A. 1992:89:6711-5.

17. Mocellin S, Bronte V, Nitti D. Nitric oxide, a double edged sword in cancer biology: searching for therapeutic opportunities. Med Res Rev. 2007:27:317-52

18. Muntane J, la Mata MD. Nitric oxide and cancer. World J Hepatol. 2010:2:337-44 
19. Fukumura D, Kashiwagi S, Jain RK. The role of nitric oxide in tumour progression. Nat Rev Cancer. 2006;6:521-34.

20. Xu W, Liu LZ, Loizidou M, Ahmed M, Charles IG. The role of nitric oxide in cancer. Cell Res. 2002;12:311-20.

21. Fionda C, Soriani A, Malgarini G, lannitto ML, Santoni A, Cippitelli M. Heat shock protein-90 inhibitors increase $\mathrm{MHC}$ class I-related chain A and B ligand expression on multiple myeloma cells and their ability to trigger NK cell degranulation. J Immunol. 2009;183:4385-94

22. Fionda C, Malgarini G, Soriani A, Zingoni A, Cecere F, lannitto ML, et al. Inhibition of glycogen synthase kinase-3 increases NKG2D ligand MICA expression and sensitivity to NK cell-mediated cytotoxicity in multiple myeloma cells: role of STAT3. J Immunol. 2013;190:6662-72.

23. Ardolino M, Zingoni A, Cerboni C, Cecere F, Soriani A, lannitto ML, et al. DNAM-1 ligand expression on Ag-stimulated T lymphocytes is mediated by ROS-dependent activation of DNA-damage response: relevance for NK-T cell interaction. Blood. 2011;117:4778-86.

24. Soriani A, lannitto ML, Ricci B, Fionda C, Malgarini G, Morrone S, et al. Reactive oxygen species- and DNA damage response-dependent NK cell activating ligand upregulation occurs at transcriptional levels and requires the transcriptional factor E2F1. J Immunol. 2014;193:950-60.

25. Mainiero F, Soriani A, Strippoli R, Jacobelli J, Gismondi A, Piccoli M, et al. RAC1/P38 MAPK signaling pathway controls beta1 integrin-induced interleukin-8 production in human natural killer cells. Immunity. 2000;12:7-16.

26. Cippitelli M, Fionda C, Di Bona D, Di Rosa F, Lupo A, Piccoli M, et al. Negative regulation of CD95 ligand gene expression by vitamin D3 in T lymphocytes. J Immunol. 2002;168:1154-66.

27. Wei L, Gravitt PE, Song H, Maldonado AM, Ozbun MA. Nitric oxide induces early viral transcription coincident with increased DNA damage and mutation rates in human papillomavirus-infected cells. Cancer Res. 2009;69:4878-84.

28. Bove PF, Hristova M, Wesley UV, Olson N, Lounsbury KM, van der Vliet A. Inflammatory levels of nitric oxide inhibit airway epithelial cell migration by inhibition of the kinase ERK1/2 and activation of hypoxia-inducible factor-1 alpha. J Biol Chem. 2008;283:17919-28.

29. Yu X, Harden K, Gonzalez LC, Francesco M, Chiang E, Irving B, et al. The surface protein TIGIT suppresses T cell activation by promoting the generation of mature immunoregulatory dendritic cells. Nat Immunol. 2009;10:48-57.

30. Stanietsky N, Simic H, Arapovic J, Toporik A, Levy O, Novik A, et al. The interaction of TIGIT with PVR and PVRL2 inhibits human NK cell cytotoxicity. Proc Natl Acad Sci U S A. 2009;106:17858-63.

31. Murad F. Regulation of cytosolic guanylyl cyclase by nitric oxide: the NO-cyclic GMP signal transduction system. Adv Pharmacol. 1994;26:19-33.

32. Kots AY, Bian K, Murad F. Nitric oxide and cyclic GMP signaling pathway as a focus for drug development. Curr Med Chem. 2011;18:3299-305.

33. Abi-Gerges N, Hove-Madsen L, Fischmeister R, Mery PF. A comparative study of the effects of three guanylyl cyclase inhibitors on the L-type Ca2+ and muscarinic K+ currents in frog cardiac myocytes. Br J Pharmacol. 1997;121:1369-77.

34. Sandirasegarane L, Diamond J. The nitric oxide donors, SNAP and DEA/NO, exert a negative inotropic effect in rat cardiomyocytes which is independent of cyclic GMP elevation. J Mol Cell Cardiol. 1999;31:799-808.

35. Thomas DD, Ridnour LA, Isenberg JS, Flores-Santana W, Switzer CH, Donzelli $\mathrm{S}$, et al. The chemical biology of nitric oxide: implications in cellular signaling. Free Radic Biol Med. 2008;45:18-31.

36. Martinez MC, Andriantsitohaina R. Reactive nitrogen species: molecular mechanisms and potential significance in health and disease. Antioxid Redox Signal. 2009;11:669-702.

37. Burney S, Caulfield JL, Niles JC, Wishnok JS, Tannenbaum SR. The chemistry of DNA damage from nitric oxide and peroxynitrite. Mutat Res. 1999;424:37-49.

38. Bartkova J, Horejsi Z, Koed K, Kramer A, Tort F, Zieger K, et al. DNA damage response as a candidate anti-cancer barrier in early human tumorigenesis. Nature. 2005;434:864-70.

39. Sancar A, Lindsey-Boltz LA, Unsal-Kacmaz K, Linn S. Molecular mechanisms of mammalian DNA repair and the DNA damage checkpoints. Annu Rev Biochem. 2004;73:39-85.

40. Sarkaria JN, Busby EC, Tibbetts RS, Roos P, Taya Y, Karnitz LM, et al. Inhibition of ATM and ATR kinase activities by the radiosensitizing agent, caffeine. Cancer Res. 1999;59:4375-82.

41. Carcagno AL, Ogara MF, Sonzogni SV, Marazita MC, Sirkin PF, Ceruti JM, et al. E2F1 transcription is induced by genotoxic stress through ATM/ATR activation. IUBMB Life. 2009;61:537-43.
42. Lin WC, Lin FT, Nevins JR. Selective induction of E2F1 in response to DNA damage, mediated by ATM-dependent phosphorylation. Genes Dev. 2001;15:1833-44.

43. Biswas AK, Johnson DG. Transcriptional and nontranscriptional functions of E2F1 in response to DNA damage. Cancer Res. 2012;72:13-7.

44. Tesei A, Zoli W, Fabbri F, Leonetti C, Rosetti M, Bolla M, et al. NCX 4040, an NO-donating acetylsalicylic acid derivative: efficacy and mechanisms of action in cancer cells. Nitric Oxide. 2008;19:225-36.

45. Shami PJ, Saavedra JE, Wang LY, Bonifant CL, Diwan BA, Singh SV, et al. JS-K, a glutathione/glutathione S-transferase-activated nitric oxide donor of the diazeniumdiolate class with potent antineoplastic activity. Mol Cancer Ther 2003;2:409-17.

46. Kiziltepe T, Hideshima T, Ishitsuka K, Ocio EM, Raje N, Catley L, et al. JS-K, a GST-activated nitric oxide generator, induces DNA double-strand breaks, activates DNA damage response pathways, and induces apoptosis in vitro and in vivo in human multiple myeloma cells. Blood. 2007;1 10:709-18.

47. Ullrich E, Bonmort M, Mignot G, Kroemer G, Zitvogel L. Tumor stress, cell death and the ensuing immune response. Cell Death Differ. 2008;15:21-8.

48. Zitvogel L, Apetoh L, Ghiringhelli F, Andre F, Tesniere A, Kroemer G. The anticancer immune response: indispensable for therapeutic success? J Clin Invest. 2008;118:1991-2001.

49. Zitvogel L, Galluzzi L, Smyth MJ, Kroemer G. Mechanism of action of conventional and targeted anticancer therapies: reinstating immunosurveillance. Immunity. 2013;39:74-88.

50. Vacchelli E, Vitale I, Tartour E, Eggermont A, Sautes-Fridman C, Galon J, et al. Trial Watch: Anticancer radioimmunotherapy. Oncoimmunology. 2013;2:e25595.

51. Gasser S. DNA damage response and development of targeted cancer treatments. Ann Med. 2007;39:457-64

52. Armeanu S, Bitzer M, Lauer UM, Venturelli S, Pathil A, Krusch M, et al. Natura killer cell-mediated lysis of hepatoma cells via specific induction of NKG2D ligands by the histone deacetylase inhibitor sodium valproate. Cancer Res. 2005;65:6321-9.

53. Wu X, Tao Y, Hou J, Meng X, Shi J. Valproic acid upregulates NKG2D ligand expression through an ERK-dependent mechanism and potentially enhances NK cell-mediated lysis of myeloma. Neoplasia. 2012;14:1178-89.

54. Cerboni C, Fionda C, Soriani A, Zingoni A, Doria M, Cippitelli M, et al. The DNA damage response: a common pathway in the regulation of NKG2D and DNAM-1 ligand expression in normal, infected, and cancer cells. Front Immunol. 2014;4:508.

55. Shi Q, Xiong Q, Wang B, Le X, Khan NA, Xie K. Influence of nitric oxide synthase II gene disruption on tumor growth and metastasis. Cancer Res. 2000;60:2579-83.

56. Xu L, Xie K, Fidler IJ. Therapy of human ovarian cancer by transfection with the murine interferon beta gene: role of macrophage-inducible nitric oxide synthase. Hum Gene Ther. 1998;9:2699-708.

57. Bruns CJ, Shinohara H, Harbison MT, Davis DW, Nelkin G, Killion JJ, et al. Therapy of human pancreatic carcinoma implants by irinotecan and the oral immunomodulator JBT 3002 is associated with enhanced expression of inducible nitric oxide synthase in tumor-infiltrating macrophages. Cancer Res. 2000;60:2-7.

58. Di CE, Comes A, Basso S, De AA, Meazza R, Musiani P, et al. The combined action of IL-15 and IL-12 gene transfer can induce tumor cell rejection without T and NK cell involvement. J Immunol. 2000;165:3111-8.

59. Jyothi MD, Khar A. Induction of nitric oxide production by natural killer cells: its role in tumor cell death. Nitric Oxide. 1999;3:409-18.

60. Cifone MG, Ulisse S, Santoni A. Natural killer cells and nitric oxide. Int Immunopharmacol. 2001;1:1513-24.

61. Perrotta C, Falcone S, Capobianco A, Camporeale A, Sciorati C, De PC, et al. Nitric oxide confers therapeutic activity to dendritic cells in a mouse model of melanoma. Cancer Res. 2004;64:3767-71.

62. Wang HH, Mclntosh AR, Hasinoff BB, Rector ES, Ahmed N, Nance DM, et al. B16 melanoma cell arrest in the mouse liver induces nitric oxide release and sinusoidal cytotoxicity: a natural hepatic defense against metastasis. Cancer Res. 2000;60:5862-9.

63. Qiu H, Orr FW, Jensen D, Wang HH, Mclntosh AR, Hasinoff BB, et al. Arrest of B16 melanoma cells in the mouse pulmonary microcirculation induces endothelial nitric oxide synthase-dependent nitric oxide release that is cytotoxic to the tumor cells. Am J Pathol. 2003;162:403-12.

64. Gasser S, Orsulic S, Brown EJ, Raulet DH. The DNA damage pathway regulates innate immune system ligands of the NKG2D receptor. Nature. 2005;436:1186-90. 
65. Shami PJ, Saavedra JE, Bonifant CL, Chu J, Udupi V, Malaviya S, et al. Antitumor activity of JS-K [O2-(2,4-dinitrophenyl) 1-[(4-ethoxycarbonyl)piperazin-1yl]diazen-1-ium-1,2-diolate] and related O2-aryl diazeniumdiolates in vitro and in vivo. J Med Chem. 2006:49:4356-66.

66. Kiziltepe T, Anderson KC, Kutok JL, Jia L, Boucher KM, Saavedra JE, et al. JS-K has potent anti-angiogenic activity in vitro and inhibits tumour angiogenesis in a multiple myeloma model in vivo. J Pharm Pharmacol. 2010;62:145-51.

67. Zheng H, Yu X, Collin-Osdoby P, Osdoby P. RANKL stimulates inducible nitric-oxide synthase expression and nitric oxide production in developing osteoclasts. An autocrine negative feedback mechanism triggered by RANKL-induced interferon-beta via NF-kappaB that restrains osteoclastogenesis and bone resorption. J Biol Chem. 2006;281:15809-20.

68. Weiss JM, Ridnour LA, Back T, Hussain SP, He P, Maciag AE, et al. Macrophage-dependent nitric oxide expression regulates tumor cell detachment and metastasis after IL-2/anti-CD40 immunotherapy. J Exp Med. 2010;207:2455-67.

69. Klug F, Prakash H, Huber PE, Seibel T, Bender N, Halama N, et al. Low-dose irradiation programs macrophage differentiation to an iNOS(+)/M1 phenotype that orchestrates effective T cell immunotherapy. Cancer Cell. 2013;24:589-602.

70. Berardi S, Ria R, Reale A, De LA, Catacchio I, Moschetta M, et al. Multiple myeloma macrophages: pivotal players in the tumor microenvironment. J Oncol. 2013;2013:183602.

71. Siemens DR, Hu N, Sheikhi AK, Chung E, Frederiksen LJ, Pross H, et al. Hypoxia increases tumor cell shedding of MHC class I chain-related molecule: role of nitric oxide. Cancer Res. 2008;68:4746-53.

72. Barsoum IB, Hamilton TK, Li X, Cotechini T, Miles EA, Siemens DR, et al. Hypoxia induces escape from innate immunity in cancer cells via increased expression of ADAM10: role of nitric oxide. Cancer Res. 2011;71:7433-41.

\section{Submit your next manuscript to BioMed Central and take full advantage of:}

- Convenient online submission

- Thorough peer review

- No space constraints or color figure charges

- Immediate publication on acceptance

- Inclusion in PubMed, CAS, Scopus and Google Scholar

- Research which is freely available for redistribution 